\title{
Electrical insulation properties of the perfluoronitrile C4F7N
}

\section{Journal Article}

Author(s):

Chachereau, Alise (D); Hösl, Andreas (D); Franck, Christian (D)

Publication date:

2018-12-12

Permanent link:

https://doi.org/10.3929/ethz-b-000262561

\section{Rights / license:}

Creative Commons Attribution-NonCommercial-NoDerivatives 4.0 International

\section{Originally published in:}

Journal of Physics D: Applied Physics 51(49), https://doi.org/10.1088/1361-6463/aae458 
This is an author-created, un-copyedited version of the article accepted by J. Phys. D: Appl. Phys. IOP Publishing Ltd is not responsible for any errors or omissions in this version of the manuscript or any version derived from it. . The Version of Record is available online at https://doi.org/10.1088/1361-6463/aae458

\title{
Electrical insulation properties of the perfluoronitrile $\mathrm{C}_{4} \mathrm{~F}_{7} \mathrm{~N}$
}

\author{
A. Chachereau ${ }^{1}$, A. Hösl ${ }^{1}$, C. M. Franck ${ }^{1}$ \\ ${ }^{1}$ Power Systems and High Voltage Laboratories, ETH Zurich, Physikstr. 3, 8092 Zurich, Switzerland \\ E-mail: alisec@ethz.ch
}

\begin{abstract}
The electrical insulation properties of pure $\mathrm{C}_{4} \mathrm{~F}_{7} \mathrm{~N}$ and of $\mathrm{C}_{4} \mathrm{~F}_{7} \mathrm{~N} / \mathrm{N}_{2}$ and $\mathrm{C}_{4} \mathrm{~F}_{7} \mathrm{~N} / \mathrm{CO}_{2}$ mixtures are investigated in a pulsed Townsend setup. The electron rate and transport coefficients and the density-reduced critical electric field of these mixtures are obtained, and a synergy effect is observed in $\mathrm{C}_{4} \mathrm{~F}_{7} \mathrm{~N} / \mathrm{N}_{2}$ and $\mathrm{C}_{4} \mathrm{~F}_{7} \mathrm{~N} / \mathrm{CO}_{2}$ mixtures. The total electron attachment cross section of $\mathrm{C}_{4} \mathrm{~F}_{7} \mathrm{~N}$ is estimated based on the attachment rate to $\mathrm{C}_{4} \mathrm{~F}_{7} \mathrm{~N}$ in diluted $\mathrm{C}_{4} \mathrm{~F}_{7} \mathrm{~N} / \mathrm{N}_{2}, \mathrm{C}_{4} \mathrm{~F}_{7} \mathrm{~N} / \mathrm{CO}_{2}$ and $\mathrm{C}_{4} \mathrm{~F}_{7} \mathrm{~N} / \mathrm{O}_{2} / \mathrm{CO}_{2}$ mixtures. Measurements in pure $\mathrm{C}_{4} \mathrm{~F}_{7} \mathrm{~N}$ at pressures of a few hundred pascal show that ion kinetics play a major role in $\mathrm{C}_{4} \mathrm{~F}_{7} \mathrm{~N}_{\text {discharges }}$ and that further modelling is required to assess the electric strength of $\mathrm{C}_{4} \mathrm{~F}_{7} \mathrm{~N}$ at high pressures.
\end{abstract}

\section{Introduction}

The perfluorinated nitrile $\left(\mathrm{CF}_{3}\right)_{2} \mathrm{CFC} \equiv \mathrm{N}$, which we refer to in the following as $\mathrm{C}_{4} \mathrm{~F}_{7} \mathrm{~N}$, has been proposed as an environment-friendly alternative to $\mathrm{SF}_{6}$ in high voltage gaseous electrical insulation $[1,2]$. The first pilot installations using this gas are a $420 \mathrm{kV}$ gas insulated line in Sellinge, UK [3] and a $145 \mathrm{kV}$ gas insulated substation in Etzel, Switzerland. The manufacturer reports a low toxicity and recommends an occupational exposure limit of $65 \mathrm{ppm}$ for $\mathrm{C}_{4} \mathrm{~F}_{7} \mathrm{~N}$ [4]. Different estimations place the GWP of $\mathrm{C}_{4} \mathrm{~F}_{7} \mathrm{~N}$ on a 100 year time horizon between 1490 and 3646 , with an atmospheric lifetime between 22 and 47 years $[4,5,6]$. The main removal mechanism of $\mathrm{C}_{4} \mathrm{~F}_{7} \mathrm{~N}$ from the atmosphere is reactions with hydroxyl radicals $[4,5,6]$. Due to the limited vapor pressure of $\mathrm{C}_{4} \mathrm{~F}_{7} \mathrm{~N}$, mixtures of 4 to $10 \% \mathrm{C}_{4} \mathrm{~F}_{7} \mathrm{~N}$ in $\mathrm{CO}_{2}$ (in some cases, up to $10 \% \mathrm{CO}_{2}$ is replaced by $\mathrm{O}_{2}$ ) are used in electrical insulation with minimum operating temperatures of down to $-25^{\circ} \mathrm{C}$ [7]. The GWP of these mixtures range from 230 to 1240 , which is a significant reduction compared to the GWP of $\mathrm{SF}_{6}$ of 23500 [8].

In this work, we investigate both $\mathrm{C}_{4} \mathrm{~F}_{7} \mathrm{~N} / \mathrm{CO}_{2}$ and $\mathrm{C}_{4} \mathrm{~F}_{7} \mathrm{~N} / \mathrm{N}_{2}$ mixtures in a pulsed Townsend setup. We start with the description of the experimental setup, the experimental conditions and the measurement analysis. In the second part of this work, we present measurement results in diluted mixtures of $\mathrm{C}_{4} \mathrm{~F}_{7} \mathrm{~N}$ in $\mathrm{N}_{2}$, in $\mathrm{CO}_{2}$ and in a $95 \% \mathrm{O}_{2} / 5 \% \mathrm{CO}_{2}$ mixture, and use these to estimate the electron attachment cross section of $\mathrm{C}_{4} \mathrm{~F}_{7} \mathrm{~N}$. In pure $\mathrm{C}_{4} \mathrm{~F}_{7} \mathrm{~N}$ at pressures of several hundred pascal, we show that the measured current is largely influenced by ion kinetic processes. Therefore, we restrict ourselves to low pressures and present the rate coefficients of ionization, attachment, and effective ionization, as well as the electron drift velocity and the longitudinal electron diffusion coefficient. Furthermore, we measure the properties of $\mathrm{C}_{4} \mathrm{~F}_{7} \mathrm{~N} / \mathrm{CO}_{2}$ and $\mathrm{C}_{4} \mathrm{~F}_{7} \mathrm{~N} / \mathrm{N}_{2}$ mixtures with $\mathrm{C}_{4} \mathrm{~F}_{7} \mathrm{~N}$ percentages up to $40 \%$, in order to investigate the synergism of the density-reduced critical electric field. We compare these results to those in $\mathrm{C}_{4} \mathrm{~F}_{7} \mathrm{~N} / \mathrm{CO}_{2}$ mixtures recently obtained by Nechmi et al. using a steady-state Townsend experiment [9]. We make all our data available on the database ETHZ [10] from the LXcat project.

\section{Methods}

\subsection{Swarm experiment}

The experiment consists in measuring the electric displacement current of electrons and ions in different gas mixtures, for different ratios of the electric field to the gas density $E / N$. The gas, or gas mixture under test is filled into a stainless steel vessel containing two Rogowski electrodes with adjustable spacing $d$, across which a voltage $U$ is applied. A photocathode, i.e. a quartz covered with a double-layer of $15 \mathrm{~nm}$ magnesium and $5 \mathrm{~nm}$ palladium, is mounted at the center of the cathode. A UV-laser pulse with a wavelength of $266 \mathrm{~nm}$ and a pulse duration of $1.5 \mathrm{~ns}$ FWHM releases $10^{6}$ to $10^{7}$ electrons from the photocathode. Due to the applied electric field, the released electrons drift towards the anode and initiate an electron avalanche. Electrons colliding with gas molecules may ionize them, forming positive ions and releasing new electrons, or may be captured, forming negative ions. Ions drift as well, contributing, relative to their drift velocity, to the measured displacement current. For the present measurements, the laser power was regulated down in order to keep a total charge below $5 \times 10^{-12} \mathrm{C}$.

1.1.1. Experimental setup The measurements in the diluted $\mathrm{C}_{4} \mathrm{~F}_{7} \mathrm{~N} / \mathrm{N}_{2}, \mathrm{C}_{4} \mathrm{~F}_{7} \mathrm{~N} / \mathrm{CO}_{2}$ and $\mathrm{C}_{4} \mathrm{~F}_{7} \mathrm{~N} / \mathrm{O}_{2} / \mathrm{CO}_{2}$ mixtures presented in section 2.1 were performed 
in the pulsed Townsend setup that was described in [11], whereas the subsequent measurements with higher $\mathrm{C}_{4} \mathrm{~F}_{7} \mathrm{~N}$ percentages were performed in a newly available setup [12] which allows for more accurate electrode spacing $( \pm 10 \mu \mathrm{m}$ instead of $\pm 100 \mu \mathrm{m})$, leading to a higher accuracy in $E / N$.

1.1.2. Gas purity The vessel has a base pressure of $1 \times 10^{-6} \mathrm{~Pa}$. In order to fill a gas or gas mixture, the content of the inlet pipes is first evacuated through the vessel. Then, each of the inlet pipes is flushed with one of the gases under study. Finally, the vessel is evacuated again and closed. The residual pressure in the vessel before the gas is filled is below $0.1 \mathrm{~Pa}$. The gases used in the present work are $\mathrm{C}_{4} \mathrm{~F}_{7} \mathrm{~N}$ with a purity of at least 99 mole $\%(3 \mathrm{M}), \mathrm{N}_{2}$ with a purity of 6.0 (Carbagas), and $\mathrm{CO}_{2}$ with a purity of 4.8 (Carbagas).

\subsection{Measurement analysis}

The measured current $I_{\exp }$ is the superposition of the electron and ion currents. These two components are separated using an iterative procedure [13] and analyzed as follows.

1.2.1. Electron current analysis The electron current analysis was described in detail in a previous publication [13]. Assuming that the one-dimensional electron density along the avalanche propagation axis is Gaussian, the electron current $I_{\mathrm{e}}$ is expressed analytically for $t \geq 0$ as $[11,13]$

$$
\begin{aligned}
& I_{\mathrm{e}}(t)=\frac{I_{0}}{2} e^{k_{\mathrm{eff}} N t}\left(1-\operatorname{erf}\left(\frac{t-T_{\mathrm{e}}}{\sqrt{2 \tau_{\mathrm{D}} t}}\right)\right), \\
& I_{0}=\frac{N_{\mathrm{e}}(0) q_{0}}{T_{\mathrm{e}}},
\end{aligned}
$$

where $I_{0}$ is the electron current at time $t=0, k_{\text {eff }}$ is the effective ionization rate coefficient, $N$ is the number density of the gas, $T_{\mathrm{e}}$ is the electron drift time, which relates to the bulk electron drift velocity $w_{\mathrm{e}}$ via $T_{\mathrm{e}}=d / w_{\mathrm{e}}, \tau_{\mathrm{D}}$ is the characteristic time for longitudinal electron diffusion, which relates to the longitudinal diffusion coefficient $D_{\mathrm{L}}$ via $2 D_{\mathrm{L}}=w_{\mathrm{e}}^{2} \tau_{\mathrm{D}}, N_{\mathrm{e}}(0)$ is the number of electrons released from the photocathode and $q_{0}$ is the elementary charge.

1.2.2. Ionization and attachment rates Using the integral of the measured current $I_{\exp }$ as described in [14], the ionization and attachment rate coefficients $k_{\mathrm{i}}$ and $k_{\mathrm{a}}$ are obtained as

$$
\begin{aligned}
& k_{\mathrm{i}}=k_{\mathrm{eff}} \frac{N_{\text {charges }}^{\text {final }}-N_{\mathrm{e}}(0)}{N_{\mathrm{e}}\left(T_{\mathrm{e}}\right)-N_{\mathrm{e}}(0)}, \\
& k_{\mathrm{a}}=k_{\mathrm{i}}-k_{\text {eff }}=k_{\text {eff }} \frac{N_{\text {charges }}^{\text {final }}-N_{\mathrm{e}}\left(T_{\mathrm{e}}\right)}{N_{\mathrm{e}}\left(T_{\mathrm{e}}\right)-N_{\mathrm{e}}(0)} .
\end{aligned}
$$

where $N_{\text {charges }}^{\text {final }}$ is the final number of electrons at the instant when they reach the anode, and $N_{\text {charges }}^{\text {final }}$ is the total number of charges in the avalanche

$N_{\text {charges }}^{\text {final }}=\frac{1}{q_{0}} \int_{0}^{\infty} I_{\text {exp }}(t) \mathrm{d} t$.

As mentioned in [14], this method relies on the assumption that no ionization events occur after the electron drift time $T_{\mathrm{e}}$, for instance due to electron detachment from negative ions, since this would increase the measured current and result in overestimating the values of $k_{\mathrm{i}}$ and $k_{\mathrm{a}}$. In the limit of low pressures this assumption is justified because the ion-neutral collisions become negligible.

\subsubsection{Estimating the total electron attachment cross} section The total attachment cross section of $\mathrm{C}_{4} \mathrm{~F}_{7} \mathrm{~N}$ is estimated by two methods [15], using the effective ionization coefficient measured in diluted mixtures of $\mathrm{C}_{4} \mathrm{~F}_{7} \mathrm{~N}$ in $\mathrm{N}_{2}$, in $\mathrm{CO}_{2}$ and in the mixture of $\begin{array}{lllll}95 \% & \mathrm{O}_{2} / 5 \% & \mathrm{CO}_{2} & & \end{array}$ $\mathrm{C}_{4} \mathrm{~F}_{7} \mathrm{~N}$ admixture does not disturb the electron energy distribution function of the carrier gas (i.e. $\mathrm{N}_{2}, \mathrm{CO}_{2}$ or $\left.95 \% \mathrm{O}_{2} / 5 \% \mathrm{CO}_{2}\right)$. In this case, the relation between the attachment cross section of $\mathrm{C}_{4} \mathrm{~F}_{7} \mathrm{~N} \sigma_{\mathrm{a}}$ and the measured values of $k_{\text {eff }}$ in the $\mathrm{C}_{4} \mathrm{~F}_{7} \mathrm{~N}$ mixtures is

$$
\begin{aligned}
k_{\text {eff }}^{\text {[mixture }]} & =(1-x) k_{\text {eff }}^{\text {[carrier gas }]} \\
& +x \sqrt{\frac{2}{m_{\mathrm{e}}}} \int_{0}^{\infty}\left(\sigma_{\mathrm{i}}-\sigma_{\mathrm{a}}\right) \varepsilon f^{[\text {carrier gas }]} \mathrm{d} \varepsilon,
\end{aligned}
$$

where $x$ is the mole fraction of $\mathrm{C}_{4} \mathrm{~F}_{7} \mathrm{~N}$ in the mixture, $m_{\mathrm{e}}$ is the electron mass, $\sigma_{\mathrm{i}}$ is the ionization cross section of $\mathrm{C}_{4} \mathrm{~F}_{7} \mathrm{~N}$ and $f^{\text {[carrier gas] }}$ is the electron energy distribution function in the carrier gas. At the considered low mole fractions of $\mathrm{C}_{4} \mathrm{~F}_{7} \mathrm{~N}$ and low $E / N$ values, the contribution of the ionization cross section $\sigma_{\mathrm{i}}$ of $\mathrm{C}_{4} \mathrm{~F}_{7} \mathrm{~N}$ is negligible. This was verified using the calculated ionization cross section of $\mathrm{C}_{4} \mathrm{~F}_{7} \mathrm{~N}$ by Xiong et al. [16].

The first method to obtain the attachment cross section of $\mathrm{C}_{4} \mathrm{~F}_{7} \mathrm{~N}$ is a linear inversion method, which makes no assumption on the shape of the cross section and requires no initial guess of the solution. We denote by $\sigma_{\mathrm{a}}^{(\mathrm{li})}$ the cross section obtained by this method. The second method is a Gaussian expansion, i.e. the shape of the cross section is approximated by the sum of several Gaussian functions. Likewise, we denote by $\sigma_{\mathrm{a}}^{(\mathrm{ge})}$ the cross section obtained by this method. We find in section 2.2 that in the present case, the cross section is well fitted with two terms, i.e.

$\sigma_{\mathrm{a}}^{(\mathrm{ge})}(\varepsilon)=\sum_{i=1}^{2} c_{\mathrm{i}} e^{-\left(\varepsilon-\varepsilon_{\mathrm{i}}\right)^{2} /\left(2 s_{\mathrm{i}}^{2}\right)}$,

where $c_{i}, \varepsilon_{i}$ and $s_{i}$ are the amplitude, position and width of the Gaussian peaks, determined by the fit. 
Table 1. Overview of the measurements in the diluted $\mathrm{C}_{4} \mathrm{~F}_{7} \mathrm{~N} / \mathrm{N}_{2}$ and $\mathrm{C}_{4} \mathrm{~F}_{7} \mathrm{~N} / \mathrm{CO}_{2}$ mixtures.

\begin{tabular}{l|lrr}
\hline $\begin{array}{c}\text { buffer } \\
\text { gas }\end{array}$ & $\begin{array}{c}\mathrm{C}_{4} \mathrm{~F}_{7} \mathrm{~N} \\
\mathrm{~mol} \%\end{array}$ & $\begin{array}{r}(E / N) \text {-range } \\
(\mathrm{Td})\end{array}$ & $\begin{array}{r}\text { pressures } \\
(\mathrm{kPa})\end{array}$ \\
\hline $\mathrm{N}_{2}$ & 0 & $5-180$ & 2,10 \\
& 0.010 & $2-120$ & 10 \\
& 0.050 & $15-145$ & 8,10 \\
& 0.125 & $50-160$ & 8,10 \\
\hline $\mathrm{CO}_{2}$ & 0 & $5-140$ & 2,10 \\
& 0.010 & $6-95$ & 2,10 \\
& 0.022 & $10-100$ & 10 \\
& 0.044 & $25-103$ & 8,10 \\
\hline $95 \% \mathrm{O}_{2-}-$ & 0 & $1-100$ & 1 \\
$5 \% \mathrm{CO}_{2}$ & 0.090 & $1-100$ & 1 \\
\hline
\end{tabular}

Both methods require the knowledge of the electron energy distribution function (EEDF) in the carrier gases. In the present work the EEDF in $\mathrm{N}_{2}, \mathrm{CO}_{2}$ and in the mixture of $95 \% \mathrm{O}_{2} / 5 \% \mathrm{CO}_{2}$ is obtained using the solver Bolsig + [17], with Biagi's cross section sets for $\mathrm{N}_{2}$ and $\mathrm{O}_{2}$ [18] and Phelps' cross section set for $\mathrm{CO}_{2}$ [19]. The effective ionization rate coefficient, electron drift velocity and diffusion coefficients calculated in pure $\mathrm{N}_{2}$, in pure $\mathrm{CO}_{2}$ and in the mixture of $95 \% \quad \mathrm{O}_{2} / 5 \% \quad \mathrm{CO}_{2}$ are shown in figures 1, 2 and 3 respectively.

In order to verify the assumption of an undisturbed EEDF, additional Bolsig + simulations were carried out in the $\mathrm{C}_{4} \mathrm{~F}_{7} \mathrm{~N}$ mixtures under study. The above-mentioned cross section sets were used for the carrier gases, and for $\mathrm{C}_{4} \mathrm{~F}_{7} \mathrm{~N}$ only the attachment cross section $\sigma_{\mathrm{a}}^{(\mathrm{ge})}$ obtained in the present work was considered. In the investigated $E / N$ range, no significant difference was observed between the EEDFs of the $\mathrm{C}_{4} \mathrm{~F}_{7} \mathrm{~N}$ mixtures under study and the EEDFs of the pure carrier gases.

\section{Results}

\subsection{Diluted $\mathrm{C}_{4} \mathrm{~F}_{7} \mathrm{~N} / \mathrm{N}_{2}$ and $\mathrm{C}_{4} \mathrm{~F}_{7} \mathrm{~N} / \mathrm{CO}_{2}$ mixtures}

An overview of the measurements in diluted mixtures of $\mathrm{C}_{4} \mathrm{~F}_{7} \mathrm{~N}$ with $\mathrm{N}_{2}$ and $\mathrm{CO}_{2}$ is given in table 1 . The obtained effective ionization rate coefficient, electron drift velocity and diffusion coefficient are shown in figure 1 for $\mathrm{N}_{2}$ mixtures and figure 2 for $\mathrm{CO}_{2}$ mixtures. The effective ionization coefficient in diluted $\mathrm{C}_{4} \mathrm{~F}_{7} \mathrm{~N}$ mixtures is decreasing with increasing $\mathrm{C}_{4} \mathrm{~F}_{7} \mathrm{~N}$ content due to electron attachment to $\mathrm{C}_{4} \mathrm{~F}_{7} \mathrm{~N}$.

\subsection{Electron attachment cross section}

Using the values of $k_{\text {eff }}$ obtained in the diluted $\mathrm{C}_{4} \mathrm{~F}_{7} \mathrm{~N} / \mathrm{N}_{2}$ and $\mathrm{C}_{4} \mathrm{~F}_{7} \mathrm{~N} / \mathrm{CO}_{2}$ mixtures, the total attachment cross section of $\mathrm{C}_{4} \mathrm{~F}_{7} \mathrm{~N}$ is estimated with
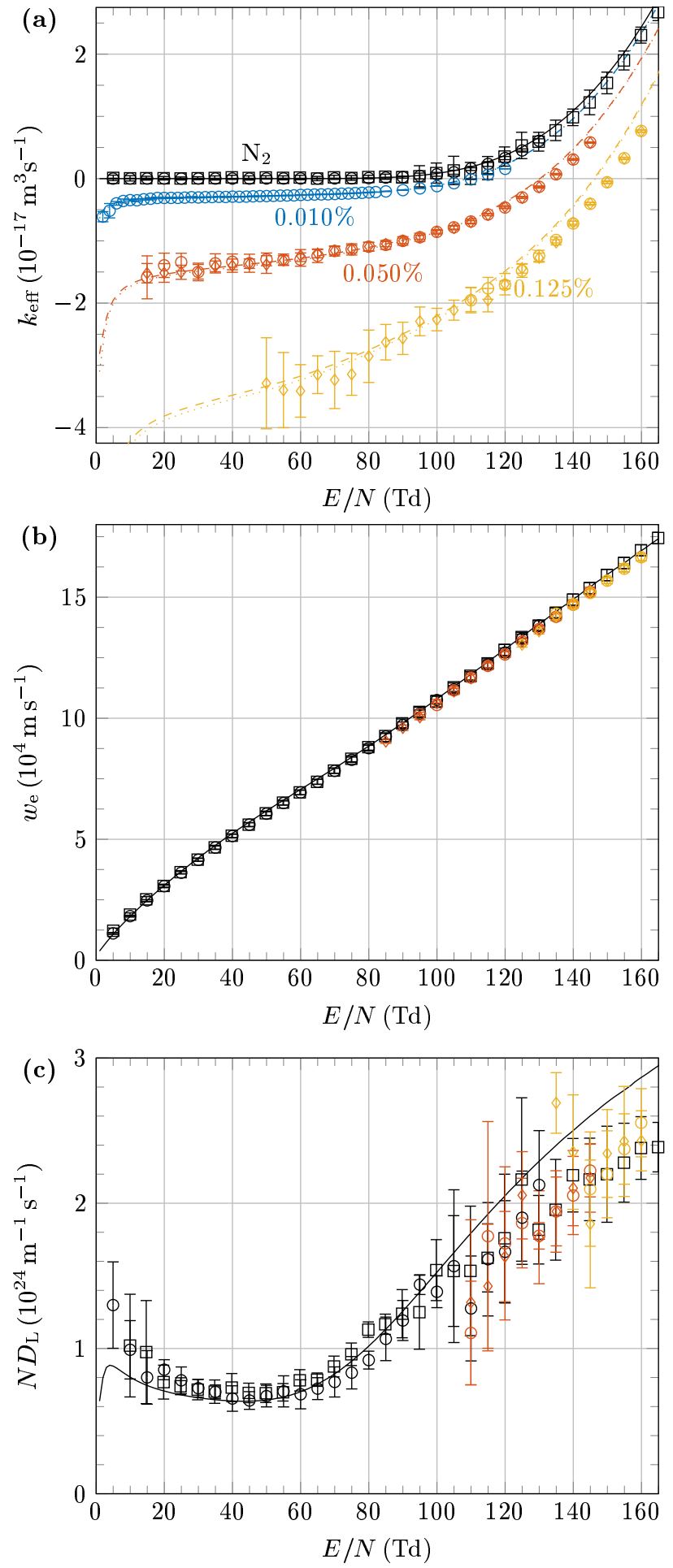

Figure 1. (a) Effective ionization rate coefficient, (b) electron drift velocity and (c) electron diffusion coefficient as functions of $E / N$ in $\mathrm{C}_{4} \mathrm{~F}_{7} \mathrm{~N} / \mathrm{N}_{2}$ mixtures. The gas mixtures are colorcoded, the $\mathrm{C}_{4} \mathrm{~F}_{7} \mathrm{~N}$ percentages are indicated in figure (a). The gas pressures are indicated with different marker shapes $(\square 2 \mathrm{kPa}$, $\diamond 8 \mathrm{kPa}, \circ 10 \mathrm{kPa})$. The lines correspond to:

$-k_{\text {eff }}, w_{\mathrm{e}}$ and $N D_{\mathrm{L}}$ in $\mathrm{N}_{2}$, calculated using Bolsig+

- - - $k_{\text {eff }}$ in $\mathrm{C}_{4} \mathrm{~F}_{7} \mathrm{~N} / \mathrm{N}_{2}$ mixtures, calculated using $\sigma_{\mathrm{a}}^{(\mathrm{li})}$

$k_{\text {eff }}$ in $\mathrm{C}_{4} \mathrm{~F}_{7} \mathrm{~N} / \mathrm{N}_{2}$ mixtures, calculated using $\sigma_{\mathrm{a}}^{\text {(ge) }}$ 

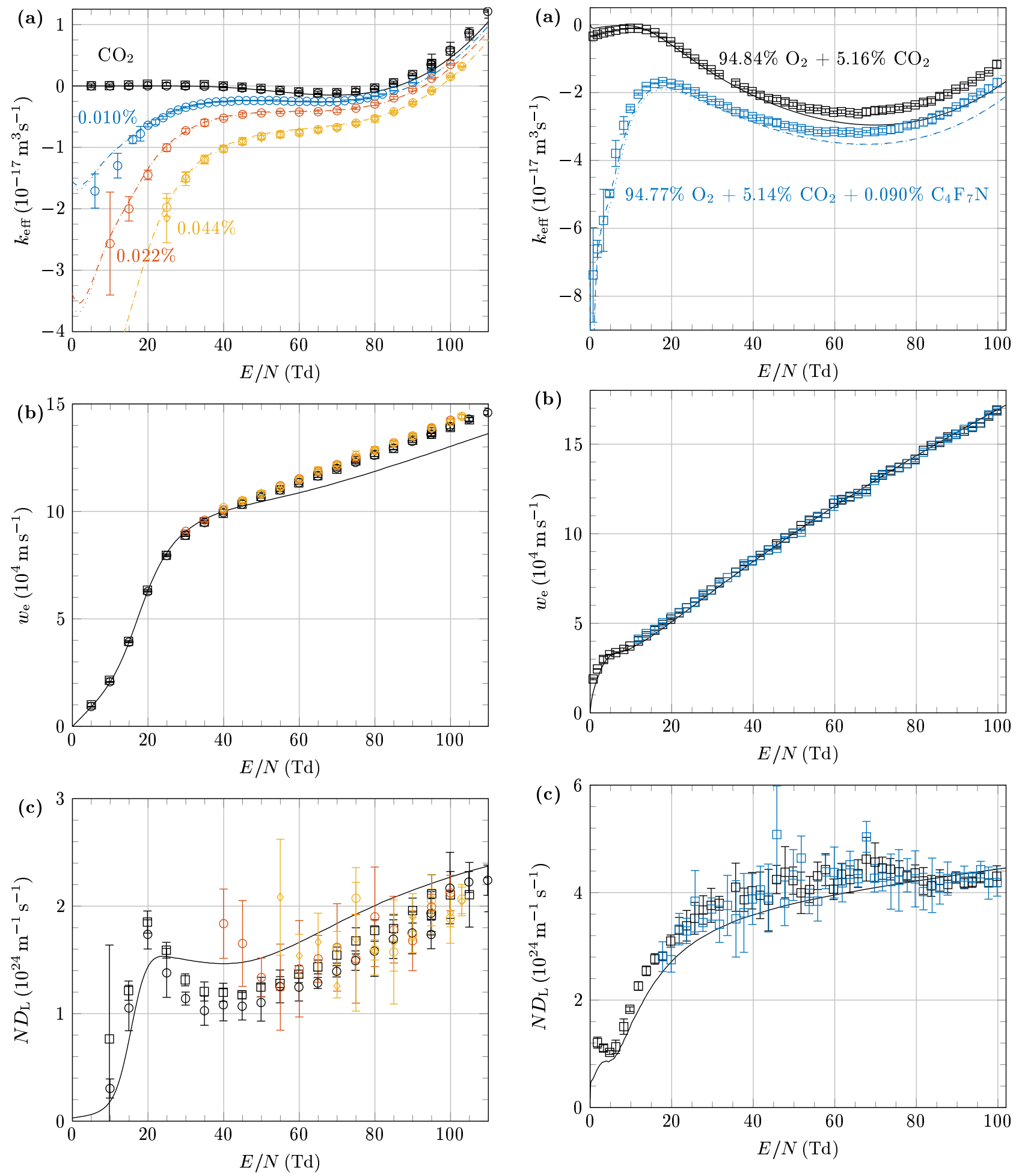

Figure 2. (a) Effective ionization rate coefficient, (b) drift velocity and (c) diffusion coefficient as functions of $E / N$ in $\mathrm{C}_{4} \mathrm{~F}_{7} \mathrm{~N} / \mathrm{CO}_{2}$ mixtures. The gas mixtures are color-coded, the $\mathrm{C}_{4} \mathrm{~F}_{7} \mathrm{~N}$ percentages are indicated in figure (a). The gas pressures are indicated with different marker shapes $(\square 2 \mathrm{kPa}, \diamond 8 \mathrm{kPa}$, o $10 \mathrm{kPa})$. The lines correspond to:

$-k_{\text {eff }}, w_{\mathrm{e}}$ and $N D_{\mathrm{L}}$ in $\mathrm{CO}_{2}$, calculated using Bolsig+

- - - $k_{\text {eff }}$ in $\mathrm{C}_{4} \mathrm{~F}_{7} \mathrm{~N} / \mathrm{CO}_{2}$ mixtures, calculated using $\sigma_{\mathrm{a}}^{(\mathrm{li})}$

$k_{\text {eff }}$ in $\mathrm{C}_{4} \mathrm{~F}_{7} \mathrm{~N} / \mathrm{CO}_{2}$ mixtures, calculated using $\sigma_{\mathrm{a}}^{(\mathrm{ge})}$

Figure 3. (a) Effective ionization rate coefficient, (b) drift velocity and (c) diffusion coefficient as functions of $E / N$ in the mixture of $5.16 \% \mathrm{CO}_{2}$ in $\mathrm{O}_{2}$ and in the mixture of $0.090 \%$ $\mathrm{C}_{4} \mathrm{~F}_{7} \mathrm{~N}$ and $5.14 \% \mathrm{CO}_{2}$ in $\mathrm{O}_{2}$, at a total pressure of $1 \mathrm{kPa}$. The gas mixtures are color-coded as indicated in figure (a). The lines correspond to:

$-k_{\text {eff }}, w_{\mathrm{e}}$ and $N D_{\mathrm{L}}$ in the $\mathrm{O}_{2} / \mathrm{CO}_{2}$ mixture, Bolsig+

- - - $k_{\text {eff }}$ in the $\mathrm{C}_{4} \mathrm{~F}_{7} \mathrm{~N} / \mathrm{O}_{2} / \mathrm{CO}_{2}$ mixture, calculated using $\sigma_{\mathrm{a}}^{(\mathrm{li})}$

$k_{\text {eff }}$ in the $\mathrm{C}_{4} \mathrm{~F}_{7} \mathrm{~N} / \mathrm{O}_{2} / \mathrm{CO}_{2}$ mixture, calculated using $\sigma_{\mathrm{a}}^{\text {(ge) }}$ 


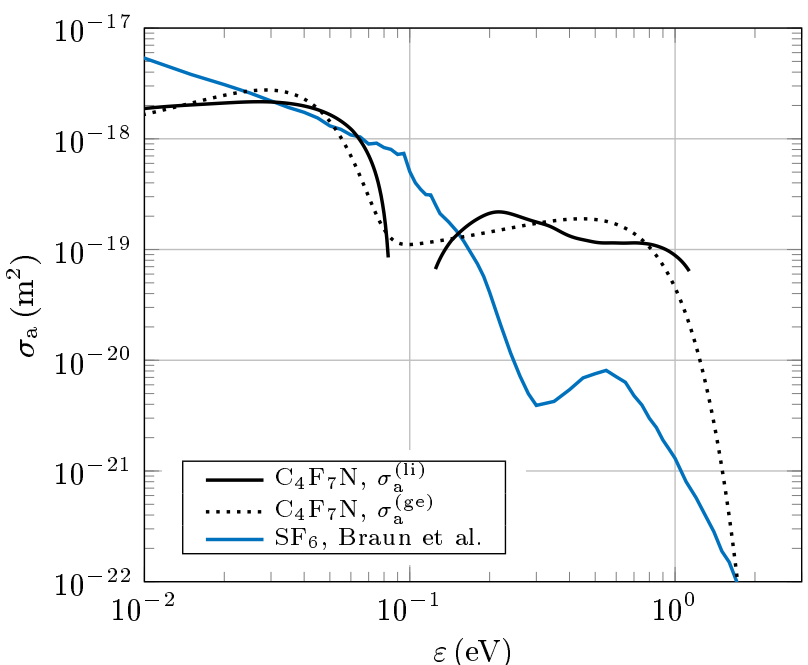

Figure 4. Total attachment cross section of $\mathrm{SF}_{6}$ and estimated total electron attachment cross section of $\mathrm{C}_{4} \mathrm{~F}_{7} \mathrm{~N}$.

the linear inversion and the Gaussian expansion methods as described in section 1.2.3. The resulting cross sections $\sigma_{\mathrm{a}}^{(\mathrm{li})}$ and $\sigma_{\mathrm{a}}^{(\mathrm{ge})}$ are shown in figure 4 , along with the electron attachment cross section of $\mathrm{SF}_{6}$ measured by Braun et al. [20]. Below $0.1 \mathrm{eV} \sigma_{\mathrm{a}}^{(\mathrm{li})}$ and $\sigma_{\mathrm{a}}^{(\mathrm{ge})}$ are in good agreement and have about the same magnitude as the cross section of $\mathrm{SF}_{6}$. Above $0.1 \mathrm{eV}$, $\sigma_{\mathrm{a}}^{(\mathrm{li})}$ and $\sigma_{\mathrm{a}}^{(\mathrm{ge})}$ are larger than the attachment cross section of $\mathrm{SF}_{6}$, and sustained up to $1 \mathrm{eV}$. The effective ionization rate coefficient in the diluted $\mathrm{C}_{4} \mathrm{~F}_{7} \mathrm{~N} / \mathrm{N}_{2}$ and $\mathrm{C}_{4} \mathrm{~F}_{7} \mathrm{~N} / \mathrm{CO}_{2}$ mixtures, was calculated using the cross sections $\sigma_{\mathrm{a}}^{(\mathrm{li})}$ and $\sigma_{\mathrm{a}}^{(\mathrm{ge})}$ to check the quality of the estimations. The calculated values of $k_{\text {eff }}$, shown in figures 1(a) and 2(a), fit perfectly with the measured values and each other over the whole $E / N$ range. It can be seen that despite the differences between $\sigma_{\mathrm{a}}^{\text {(li) }}$ and $\sigma_{\mathrm{a}}^{(\mathrm{ge})}$, both are resolved to a maximal extent based on the present measurements. For the same reason, it is not reasonable to add a third term to the Gaussian expansion $\sigma_{\mathrm{a}}^{(\mathrm{ge})}$, as the two term expansion already fits perfectly the measurements.

\subsection{Results in pure $C_{4} F_{7} N$}

Example measurements carried out in pure $\mathrm{C}_{4} \mathrm{~F}_{7} \mathrm{~N}$ at pressures up to $1 \mathrm{kPa}$ are shown in figure 5 . The measured current at $1 \mathrm{kPa}$ features a maximum at $t \sim$ $10 \mu \mathrm{s}$, i.e. on the ionic timescale, which suggests that ion kinetics play a major role in high pressure $\mathrm{C}_{4} \mathrm{~F}_{7} \mathrm{~N}$ discharges. Furthermore, when using equations (3) and (4) with measurements in $\mathrm{C}_{4} \mathrm{~F}_{7} \mathrm{~N}$ at 260 to $1000 \mathrm{~Pa}$, the obtained values for $k_{\mathrm{i}}$ and $k_{\mathrm{a}}$ increase with increasing gas pressure. These inconsistent values for $k_{\mathrm{i}}$ and $k_{\mathrm{a}}$ suggest that ionization events occur
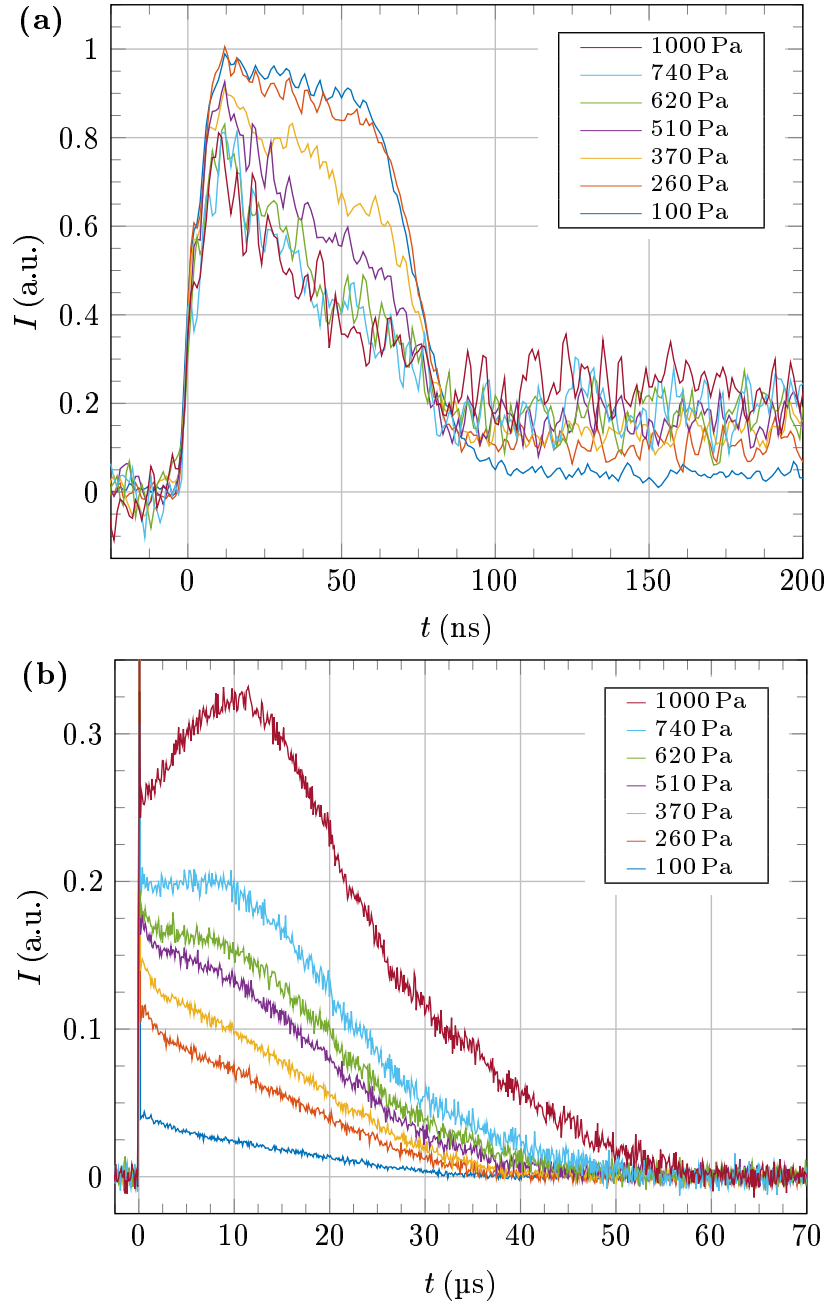

Figure 5. Current versus time in pure $\mathrm{C}_{4} \mathrm{~F}_{7} \mathrm{~N}$, at different pressures, for an electrode spacing of $25 \mathrm{~mm}$, and for a reduced electric field $E / N$ of $966 \mathrm{Td}$, (a) on the electronic timescale and (b) on the ionic timescale. The measurements are rescaled to have a similar amplitude at $t=0$, the original amplitudes ranged from $5.5 \mu \mathrm{A}$ at $100 \mathrm{~Pa}$ to $0.4 \mu \mathrm{A}$ at $1000 \mathrm{~Pa}$.

after the electron drift time $T_{\mathrm{e}}$, for instance due to electron detachment from negative ions. When the kinetic model is known, it is possible to obtain the rate coefficients for both electron and ion processes by fitting the measured current, as this was done first for humid air [21], and more recently for $\mathrm{N}_{2^{-}}$ $\mathrm{O}_{2}$ mixtures [22, 23]. However, no information is yet available as to which negative ions are formed in $\mathrm{C}_{4} \mathrm{~F}_{7} \mathrm{~N}$, and which of those might be prone to electron detachment. Therefore, the analysis of high pressure measurements in $\mathrm{C}_{4} \mathrm{~F}_{7} \mathrm{~N}$ will require first an extensive modelling of the ion kinetics. In the meantime, we restrict ourselves to low pressures where the ion kinetics are negligible. We report electron rate and transport coefficients in pure $\mathrm{C}_{4} \mathrm{~F}_{7} \mathrm{~N}$ for pressures ranging from 60 to $100 \mathrm{~Pa}$. Example measurements in $\mathrm{C}_{4} \mathrm{~F}_{7} \mathrm{~N}$ at $100 \mathrm{~Pa}$ are shown in figures 6 and 7 . 

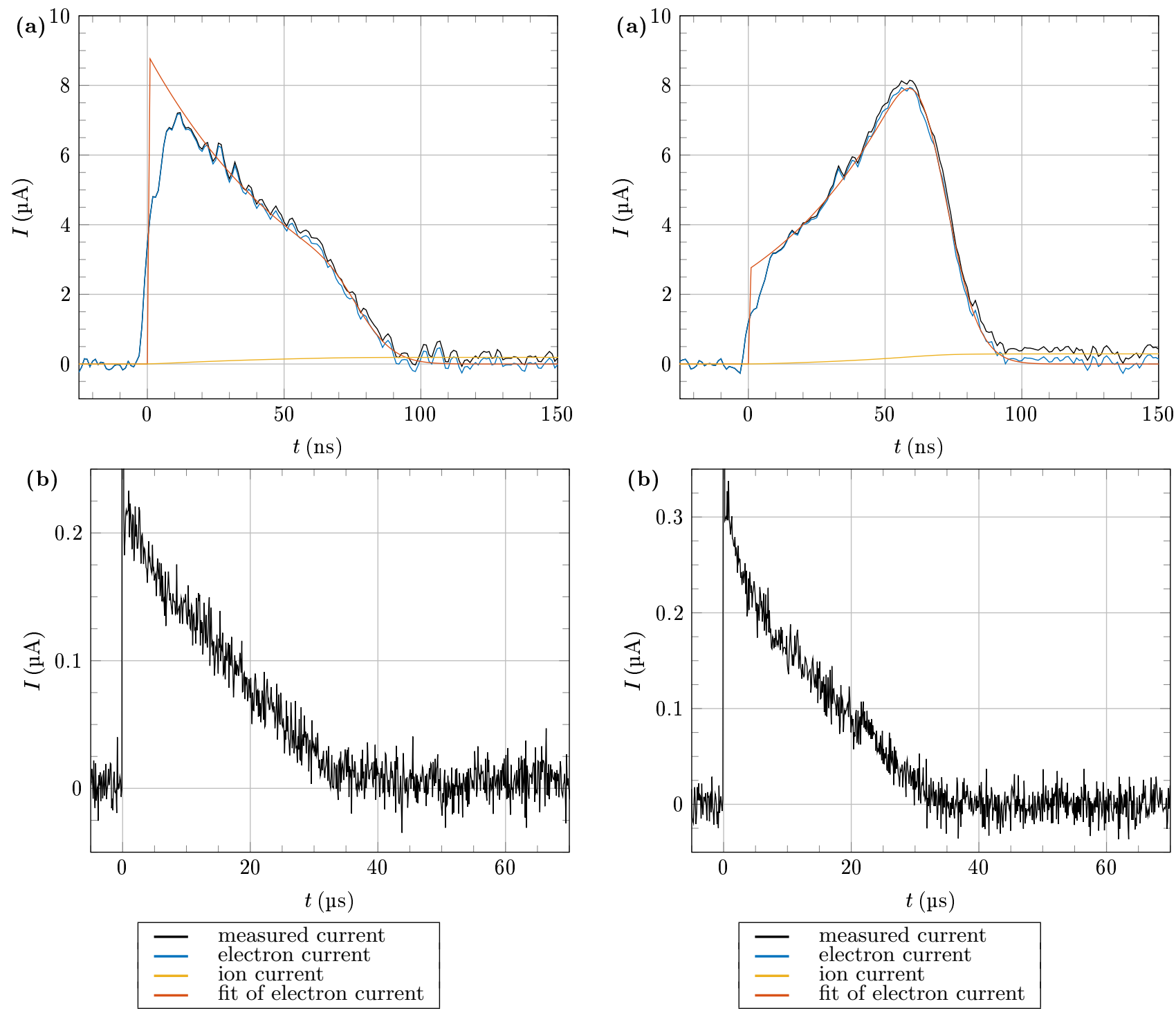

Figure 6. Current versus time in pure $\mathrm{C}_{4} \mathrm{~F}_{7} \mathrm{~N}$, at a pressure of $100 \mathrm{~Pa}$, for an electrode spacing of $25 \mathrm{~mm}$, and for a reduced electric field $E / N$ of $916 \mathrm{Td}$ (a) on the electronic timescale and (b) on the ionic timescale.

Figure 8 shows the ionization, attachment and effective ionization rate coefficients, as well as the electron drift velocity and diffusion coefficient obtained in pure $\mathrm{C}_{4} \mathrm{~F}_{7} \mathrm{~N}$ at low pressures. All these quantities are independent of the gas pressure. In particular, the fact that the obtained values of the $k_{\mathrm{i}}$ and $k_{\mathrm{a}}$ are independent of the gas pressure in the considered range of 60 to $100 \mathrm{~Pa}$ allows us to verify that electron detachment is indeed negligible at these pressures. We obtain a density-reduced critical electric field $(E / N)_{\text {crit }}$ of $975 \pm 15 \mathrm{Td}$ for pure $\mathrm{C}_{4} \mathrm{~F}_{7} \mathrm{~N}$. Since we consider here low pressures at which the ion kinetics of $\mathrm{C}_{4} \mathrm{~F}_{7} \mathrm{~N}$ are negligible, the effective ionization coefficient is defined simply as $k_{\text {eff }}=k_{\mathrm{i}}-k_{\mathrm{a}}$ and the density-reduced critical electric field is defined in the classical sense as the $E / N$

Figure 7. Current versus time in pure $\mathrm{C}_{4} \mathrm{~F}_{7} \mathrm{~N}$, at a pressure of $100 \mathrm{~Pa}$, for an electrode spacing of $25 \mathrm{~mm}$, and for a reduced electric field $E / N$ of $1047 \mathrm{Td}$ (a) on the electronic timescale and (b) on the ionic timescale.

ratio for which $k_{\mathrm{i}}=k_{\mathrm{a}}$. However, at higher pressures, ion kinetics will lead to different values of $k_{\text {eff }}$, and selfsustained discharges will occur at $E / N<(E / N)_{\text {crit }}$. Therefore, the present values of $(E / N)_{\text {crit }}$ are not directly usable at high pressures. A complete kinetic model will need to be developed for $\mathrm{C}_{4} \mathrm{~F}_{7} \mathrm{~N}$, and the reaction rate coefficients of ionic reactions will need to be determined. Once this is achieved, it will open the way for calculations to predict the discharge development in $\mathrm{C}_{4} \mathrm{~F}_{7} \mathrm{~N}$ at high pressures, as it was done for humid air [21], $\mathrm{N}_{2}-\mathrm{O}_{2}$ mixtures [22, 23, 24] and $\mathrm{CO}_{2}[25]$. 

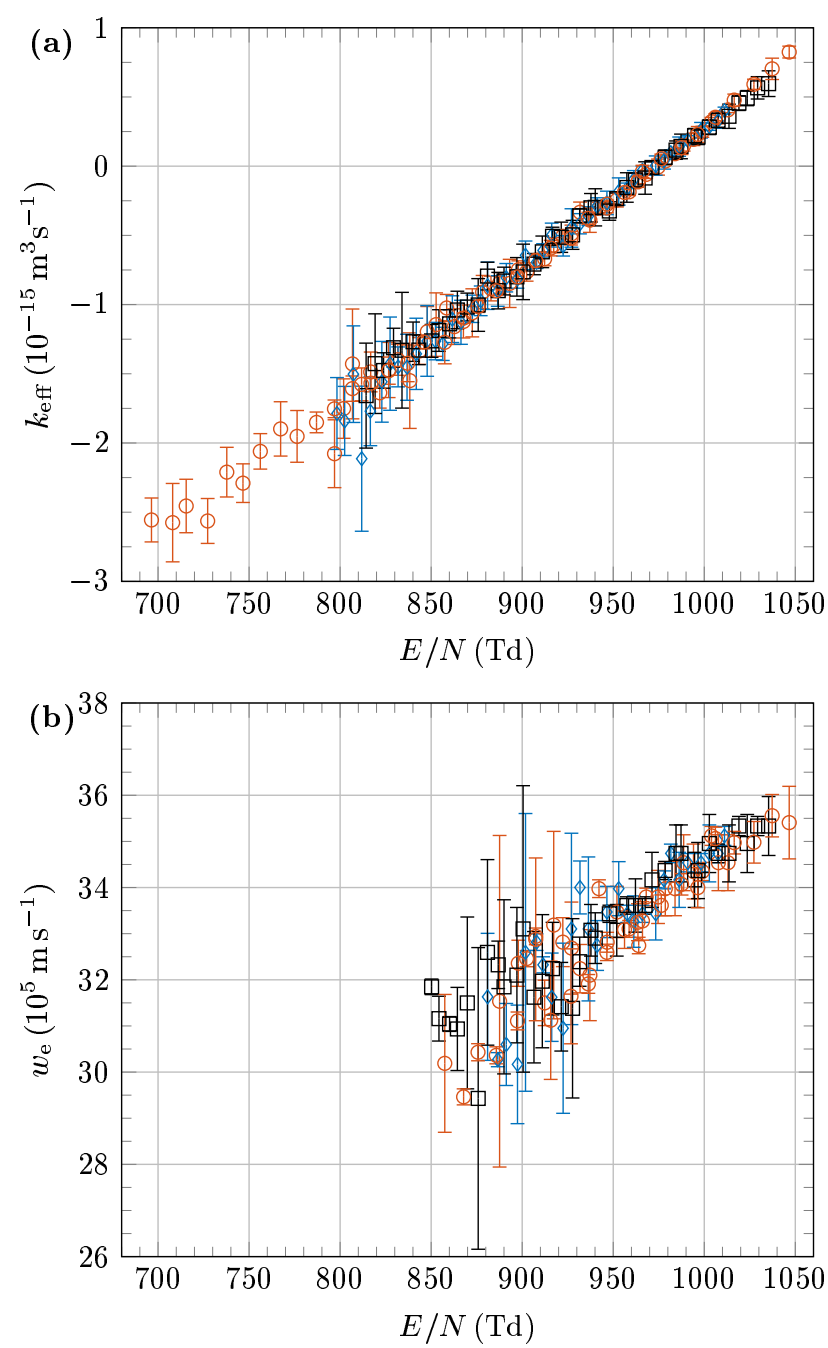

\subsection{Synergism in $C_{4} F_{7} N / N_{2}$ and $C_{4} F_{7} N / C_{2}$ mixtures}

In order to study the synergism in the density-reduced critical electric field, we measure different $\mathrm{C}_{4} \mathrm{~F}_{7} \mathrm{~N} / \mathrm{N}_{2}$ and $\mathrm{C}_{4} \mathrm{~F}_{7} \mathrm{~N} / \mathrm{CO}_{2}$ with up to $40 \% \mathrm{C}_{4} \mathrm{~F}_{7} \mathrm{~N}$. Similarly to pure $\mathrm{C}_{4} \mathrm{~F}_{7} \mathrm{~N}$, measurements at high pressures are highly influenced by ion kinetics, therefore, we limit ourselves in the present study to pressures below $100 \mathrm{~Pa}$. An overview of the measurements is given in table 2.

Figures 10 and 9 show the effective ionization rate coefficient, the electron drift velocity and the longitudinal electron diffusion coefficient obtained in $\mathrm{C}_{4} \mathrm{~F}_{7} \mathrm{~N} / \mathrm{N}_{2}$ and $\mathrm{C}_{4} \mathrm{~F}_{7} \mathrm{~N} / \mathrm{CO}_{2}$ mixtures respectively. For the $\mathrm{C}_{4} \mathrm{~F}_{7} \mathrm{~N} / \mathrm{CO}_{2}$ mixtures, only part of the measurements from table 2 are shown in figure 9 , the rest are available on the LXcat database ETHZ [10].

The density-reduced critical electric field $(E / N)_{\text {crit }}$ of $\mathrm{C}_{4} \mathrm{~F}_{7} \mathrm{~N} / \mathrm{N}_{2}$ and $\mathrm{C}_{4} \mathrm{~F}_{7} \mathrm{~N} / \mathrm{CO}_{2}$ mixtures obtained in the present work is shown in figure 11 and compared to that of $\mathrm{C}_{4} \mathrm{~F}_{7} \mathrm{~N} / \mathrm{CO}_{2}$ mixtures from Nechmi
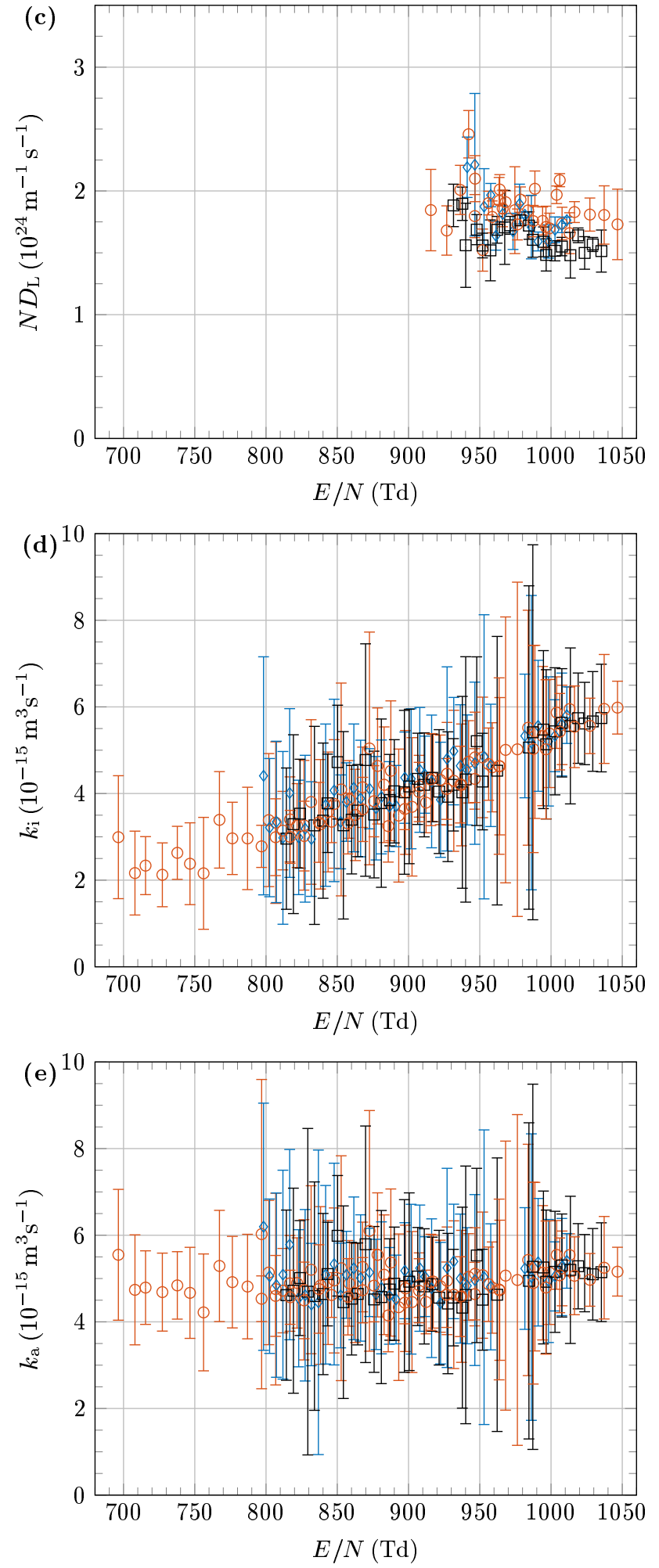

Figure 8. (a) Effective ionization rate coefficient, (b) electron drift velocity, (c) electron diffusion coefficient, (d) ionization rate coefficient and (e) attachment rate coefficient as functions of $E / N$ in $\mathrm{C}_{4} \mathrm{~F}_{7} \mathrm{~N}$, at different gas pressures $(\square 60 \mathrm{~Pa}, \diamond 80 \mathrm{~Pa}$, $\circ 100 \mathrm{~Pa}$ ). 

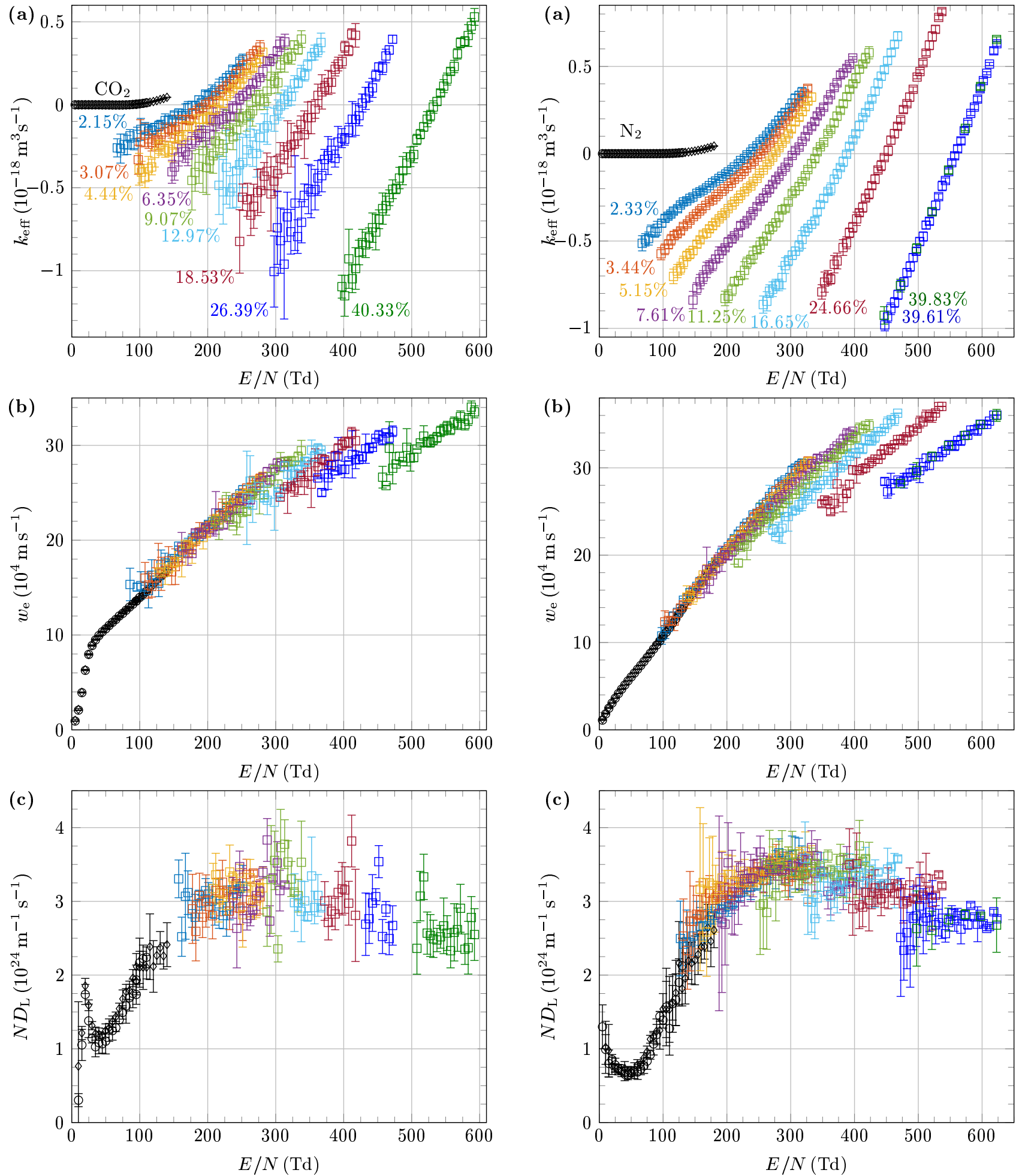

Figure 9. (a) Effective ionization rate coefficient, (b) electron drift velocity and (c) electron diffusion coefficient as functions of $E / N$ in $\mathrm{C}_{4} \mathrm{~F}_{7} \mathrm{~N} / \mathrm{CO}_{2}$ mixtures. The gas mixtures are color-coded, the $\mathrm{C}_{4} \mathrm{~F}_{7} \mathrm{~N}$ percentages are indicated in figure (a). The gas pressures are indicated with different marker shapes $(\square 100 \mathrm{~Pa}, \diamond 2 \mathrm{kPa}, \circ 10 \mathrm{kPa})$.

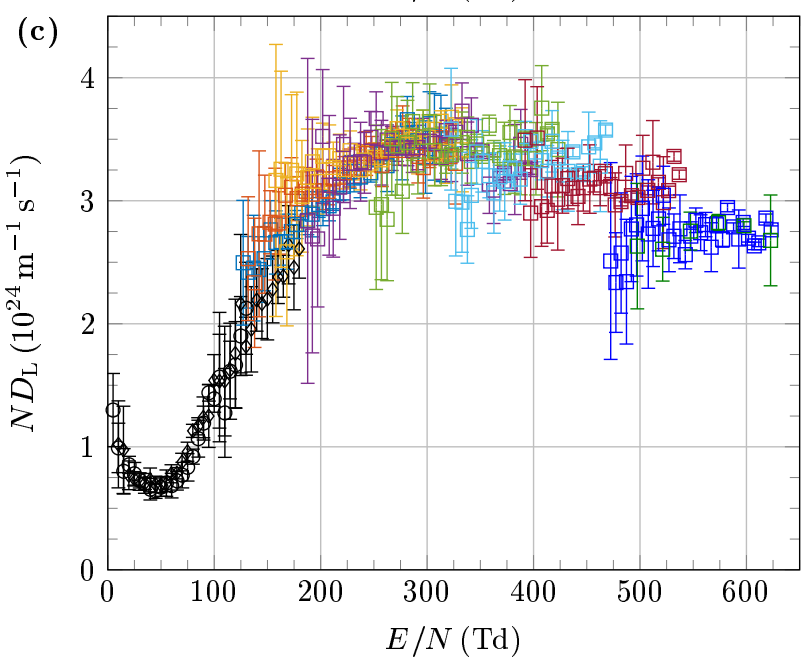

Figure 10. (a) Effective ionization rate coefficient, (b) electron drift velocity and (c) electron diffusion coefficient as functions of $E / N$ in $\mathrm{C}_{4} \mathrm{~F}_{7} \mathrm{~N} / \mathrm{N}_{2}$ mixtures. The gas mixtures are color-coded, the $\mathrm{C}_{4} \mathrm{~F}_{7} \mathrm{~N}$ percentages are indicated in figure (a). The gas pressures are indicated with different marker shapes $(\square 100 \mathrm{~Pa}, \diamond 2 \mathrm{kPa}, \circ 10 \mathrm{kPa})$. 
Table 2. Overview of the measurements in the $\mathrm{C}_{4} \mathrm{~F}_{7} \mathrm{~N} / \mathrm{N}_{2}$ and $\mathrm{C}_{4} \mathrm{~F}_{7} \mathrm{~N} / \mathrm{CO}_{2}$ mixtures.

\begin{tabular}{l|rrr}
\hline $\begin{array}{c}\text { buffer } \\
\text { gas }\end{array}$ & $\begin{array}{c}\mathrm{C}_{4} \mathrm{~F}_{7} \mathrm{~N} \\
\text { mol\% }\end{array}$ & $\begin{array}{r}(E / N) \text {-range } \\
(\mathrm{Td})\end{array}$ & \multicolumn{1}{c}{$\begin{array}{r}\text { pressures } \\
(\mathrm{Pa})\end{array}$} \\
\hline $\mathrm{N}_{2}$ & \multicolumn{1}{c}{5} & $5-180$ & 2000,10000 \\
& 2.33 & $67-318$ & 100 \\
& 3.44 & $97-327$ & 100 \\
& 5.15 & $116-333$ & 100 \\
& 7.61 & $147-397$ & 100 \\
& 11.25 & $197-423$ & 100 \\
& 16.65 & $257-468$ & 100 \\
& 24.66 & $349-537$ & 100 \\
& 39.61 & $447-623$ & 100 \\
& 39.83 & $447-623$ & 100 \\
\hline $\mathrm{CO}_{2}$ & 0 & $5-140$ & 2000,10000 \\
& 2.15 & $67-251$ & 100 \\
& 3.07 & $98-277$ & 100 \\
& 4.44 & $99-281$ & 100 \\
& 6.35 & $147-313$ & 100 \\
& 9.07 & $177-338$ & 100 \\
& 12.97 & $217-367$ & 100 \\
& 18.53 & $247-417$ & 100 \\
& 26.39 & $298-472$ & 100 \\
& 40.33 & $397-592$ & 100 \\
& 1.97 & $27-273$ & 100 \\
& 3.96 & $107-298$ & 100 \\
& 5.79 & $136-298$ & 100 \\
& 11.66 & $176-358$ & 100 \\
& 24.35 & $296-477$ & 100 \\
\hline \multirow{6}{*}{} & & &
\end{tabular}

et al. [9] and that of $\mathrm{SF}_{6} / \mathrm{N}_{2}$ and $\mathrm{SF}_{6} / \mathrm{CO}_{2}$ mixtures [26]. We observe a synergism in both $\mathrm{C}_{4} \mathrm{~F}_{7} \mathrm{~N} / \mathrm{N}_{2}$ and $\mathrm{C}_{4} \mathrm{~F}_{7} \mathrm{~N} / \mathrm{CO}_{2}$ mixtures, although the $(E / N)_{\text {crit }}$ of $\mathrm{C}_{4} \mathrm{~F}_{7} \mathrm{~N} / \mathrm{N}_{2}$ is higher than that of $\mathrm{C}_{4} \mathrm{~F}_{7} \mathrm{~N} / \mathrm{CO}_{2}$ mixtures. Mixtures of $\sim 13.5 \% \mathrm{C}_{4} \mathrm{~F}_{7} \mathrm{~N}$ in $\mathrm{N}_{2}$ or $\sim 18.5 \%$ $\mathrm{C}_{4} \mathrm{~F}_{7} \mathrm{~N}$ in $\mathrm{CO}_{2}$ would have about the same $(E / N)_{\text {crit }}$ as pure $\mathrm{SF}_{6}$, although as mentioned in section 2.3 , the values for $(E / N)_{\text {crit }}$ presently obtained at low pressures may not apply at high pressure. The $(E / N)_{\text {crit }}$ we obtain for $\mathrm{C}_{4} \mathrm{~F}_{7} \mathrm{~N} / \mathrm{CO}_{2}$ mixtures differs by up to $15 \%$ from that found by Nechmi et al.

\section{Discussion}

\subsection{Electron attachment to $C_{4} F_{7} N$}

The effective ionization rate coefficient in $\mathrm{C}_{4} \mathrm{~F}_{7} \mathrm{~N} / \mathrm{N}_{2}$ and $\mathrm{C}_{4} \mathrm{~F}_{7} \mathrm{~N} / \mathrm{CO}_{2}$ mixtures shown in figures 1 (a) and 2(a) decreases fast with decreasing $E / N$, which suggests that electron attachment to $\mathrm{C}_{4} \mathrm{~F}_{7} \mathrm{~N}$ is strongest at thermal electron energies. The present estimations of the attachment cross section might not yield the exact shape of the attachment cross section, due to the uncertainties in the EEDF of the carrier gases and the limited information content of the measurements. However, the present estimations suggest that the attachment cross section of $\mathrm{C}_{4} \mathrm{~F}_{7} \mathrm{~N}$ is similar to that of $\mathrm{SF}_{6}$ for electron energies below
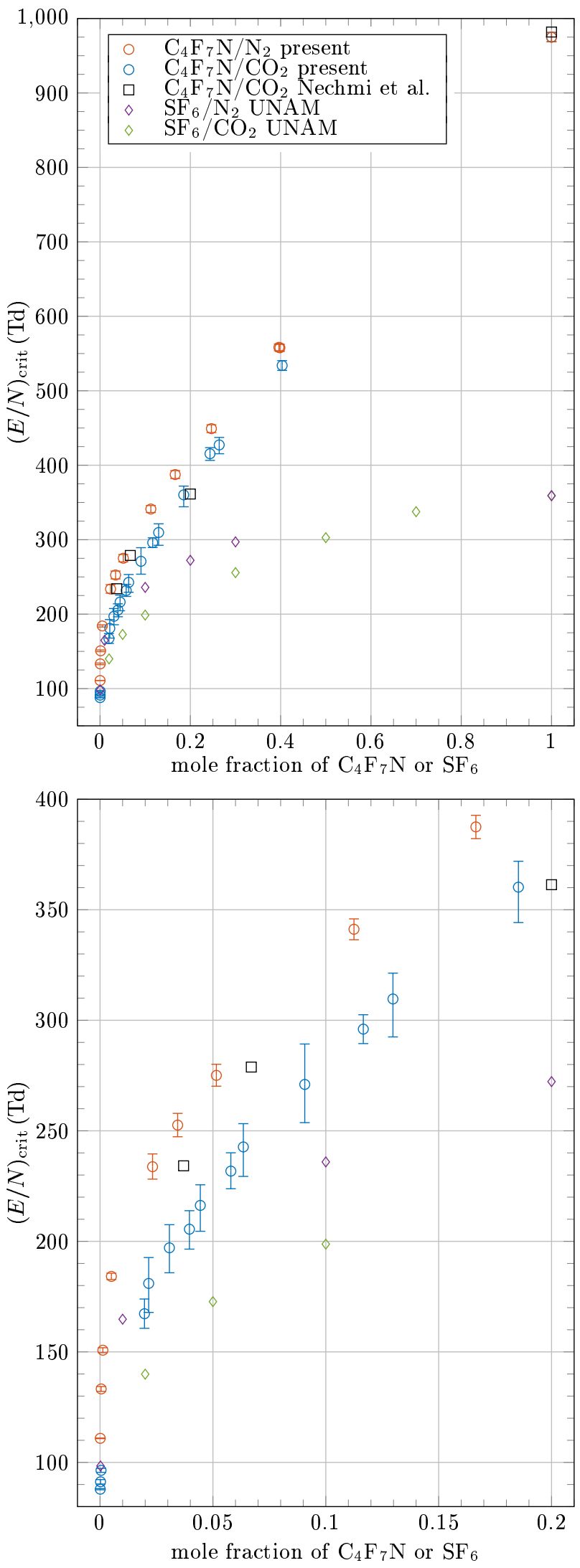

Figure 11. Density-reduced critical electric field of $\mathrm{C}_{4} \mathrm{~F}_{7} \mathrm{~N} / \mathrm{N}_{2}$, $\mathrm{C}_{4} \mathrm{~F}_{7} \mathrm{~N} / \mathrm{CO}_{2}, \mathrm{SF}_{6} / \mathrm{N}_{2}$ and $\mathrm{SF}_{6} / \mathrm{CO}_{2}$ mixtures. 
$0.1 \mathrm{eV}$, and that it is substantially larger than that of $\mathrm{SF}_{6}$ in the region between $0.1 \mathrm{eV}$ and $1 \mathrm{eV}$. The attachment around $1 \mathrm{eV}$ could be due to dissociative attachment to $\mathrm{CN}^{-}$similarly to other perfluorinated nitriles [27, 28], whereas electron attachment towards $0 \mathrm{eV}$ could be parent ion attachment to $\mathrm{C}_{4} \mathrm{~F}_{7} \mathrm{~N}^{-}$.

\subsection{Ion kinetic processes in $C_{4} F_{7} N$}

The complexity of the measured current in pure $\mathrm{C}_{4} \mathrm{~F}_{7} \mathrm{~N}$ at pressures $>100 \mathrm{~Pa}$ on the ionic time scale suggests that ion kinetics play a major role in $\mathrm{C}_{4} \mathrm{~F}_{7} \mathrm{~N}$ discharges at high pressures. From first modelling attempts, we suspect that at least two negative ion species are formed, which both exhibit electron detachment. Our present measurements at low pressures let us obtain the rate and transport coefficients of electrons. Based on these results we can attempt to model the ion kinetics in more detail in a future study.

\subsection{Density-reduced critical electric field}

The present results obtained at low pressures are insufficient to assess the performance of $\mathrm{C}_{4} \mathrm{~F}_{7} \mathrm{~N}$ as an electrical insulation gas, as the breakdown process at higher pressures might be affected by ion kinetics. We suspect this is why we obtain an $(E / N)_{\text {crit }}$ of about 2.6 times that of $\mathrm{SF}_{6}$, whereas the breakdown voltage of $\mathrm{C}_{4} \mathrm{~F}_{7} \mathrm{~N}$ is reported to be only 2 times that of $\mathrm{SF}_{6}[1,2]$.

The discrepancy in the density-reduced critical field of $\mathrm{C}_{4} \mathrm{~F}_{7} \mathrm{~N} / \mathrm{CO}_{2}$ mixtures from the present work compared to that of Nechmi et al. is likely due to a large uncertainty in the latter work. The authors give no uncertainty estimation, but the scatter in the data from figure 5 of their article suggests that a large uncertainty must be considered. In addition, the assumption made by the authors of a linearity in the logarithm of the measured current against the electrode spacing is not verified for electron attaching gases, as pointed out by Harrison and Geballe [29], and this could significantly affect their results.

\section{Conclusion}

We report electron rate and transport coefficients in pure $\mathrm{C}_{4} \mathrm{~F}_{7} \mathrm{~N}$ and in mixtures of $\mathrm{C}_{4} \mathrm{~F}_{7} \mathrm{~N}$ with $\mathrm{N}_{2}$ and $\mathrm{CO}_{2}$, and find that $\mathrm{C}_{4} \mathrm{~F}_{7} \mathrm{~N}$ has a large electron attachment cross section at thermal energies and up to $1 \mathrm{eV}$. Our measurements in $\mathrm{C}_{4} \mathrm{~F}_{7} \mathrm{~N}$ at pressures of a few hundred pascal show that ion kinetics are important in $\mathrm{C}_{4} \mathrm{~F}_{7} \mathrm{~N}$ discharges. The present results at low pressures enable us to obtain the rate and transport coefficients of electrons, which lays a solid basis for future modelling work, in which we will aim to obtain ion rate and transport coefficients in order to accurately model high pressure $\mathrm{C}_{4} \mathrm{~F}_{7} \mathrm{~N}$ discharges.

\section{Acknowledgments}

This work is financially supported by GE Grid (Switzerland) GmbH, Pfiffner Technologie AG, ABB Switzerland Ltd and Siemens AG. The sample of $\mathrm{C}_{4} \mathrm{~F}_{7} \mathrm{~N}$ was provided by GE Grid, Oberentfelden, Switzerland.

\section{References}

[1] Costello M, Flynn R and Bulinski M 2013 Fluorinated nitriles as dielectric gases WO Patent App. PCT/US2013/031,854 URL https : / / encrypted.google.com/patents/W02013151741A1?cl=en

[2] Kieffel Y, Girodet A, Biquez F, Ponchon P, Owens J, Costello M, Bulinski M, San R V and Werner K 2014 $\mathrm{SF}_{6}$ alternative development for high voltage switchgears Cigre, Paris paper D1-305 URL https://e-cigre.org/ publication/SESSION2014-2014-cigre-session-setof-papers--proceedings

[3] Laruelle E, Ficheux A, Kieffel Y and Waldron M 2017 Cigre Science \& Engineering 7 102-108 URL https: //e-cigre.org/publication/CSE007-cse-007

[4] $3 \mathrm{M}^{T M}$ Novec $^{T M} 4710$ Insulating Gas, environmental, Health and Safety Summary, Issued: 6/17 URL http://multimedia.3m.com/mws/media/14187310/ 12633-novec-insulating-gas - tech-bulletin-4710a4-celum.pdf?fn=prodinfo_novec1230.pdf

[5] Sulbaek Andersen M P, Kyte M, Andersen S T, Nielsen C J and Nielsen O J 2017 Environmental Science \& Technology 51 1321-1329 (Preprint http://dx.doi.org/ 10.1021/acs.est.6b03758) URL http://dx.doi.org/ 10.1021 /acs.est.6b03758

[6] Blàzquez S, Antiolo M, Nielsen O J, Albaladejo J and Jimnez E 2017 Chemical Physics Letters 687297 - 302 ISSN 0009-2614 URL http://www.sciencedirect.com/ science/article/pii/S0009261417308862

[7] Kieffel Y, Biquez F and Ponchon P 2015 Alternative gas to $\mathrm{SF}_{6}$ for use in high voltage switchgears: $\mathrm{g}^{3}$ Cired, Lyon paper 0230

[8] Myhre G, Shindell D, Bréon F M, Collins W, Fuglestvedt J, Huang J, Koch D, Lamarque J F, Lee D, Mendoza B, Nakajima T, Robock A, Stephens G, Takemura $\mathrm{T}$ and Zhang H 2013 Anthropogenic and natural radiative forcing Climate Change 2013: The Physical Science Basis. Contribution of Working Group I to the Fifth Assessment Report of the Intergovernmental Panel on Climate Change ed Stocker T, Qin D, Plattner G K, Tignor M, Allen S, Boschung J, Nauels A, Xia Y, Bex V and Midgley P (Cambridge, United Kingdom and New York, NY, USA: Cambridge University Press) pp 659-740 ISBN 978-1-107-66182-0 URL www.climatechange2013.org

[9] Nechmi H E, Beroual A, Girodet A and Vinson P 2017 IEEE Transactions on Dielectrics and Electrical Insulation 24 886-892 ISSN 1070-9878

[10] ETHZ database URL www.1xcat.net/ETHZ

[11] Dahl D A, Teich T H and Franck C M 2012 Journal of Physics D: Applied Physics 45485201 URL http: //stacks.iop.org/0022-3727/45/i=48/a=485201

[12] Häfliger P and Franck C M 2018 Review of Scientific Instruments 89023114 (Preprint https://doi.org/ 10.1063/1.5002762) URL https://doi.org/10.1063/ 1.5002762

[13] Chachereau A, Rabie M and Franck C M 2016 Plasma Sources Science and Technology 25045005 URL http: //stacks.iop.org/0963-0252/25/i=4/a=045005 
[14] Chachereau A, Hösl A and Franck C M 2018 J. Phys. D: Appl. Phys. 51335204 URL http://dx.doi.org/10.1088/ 1361-6463/aad174

[15] Rabie M, Haefliger P, Chachereau A and Franck C M 2015 Journal of Physics D: Applied Physics 48075201 URL http://stacks.iop.org/0022-3727/48/i=7/a=075201

[16] Xiong J, Li X, Wu J, Guo X and Zhao H 2017 Journal of Physics D: Applied Physics 50445206 URL http: //stacks.iop.org/0022-3727/50/i=44/a=445206

[17] Hagelaar G and Pitchford L 2005 Plasma Sources Science and Technology 14 722-733 ISSN 0963-0252 URL http: //dx.doi.org/10.1088/0963-0252/14/4/011

[18] Biagi database, data extracted from the fortran program MAGBOLTZ of S.F. Biagi, versions 8.9 and after, data retrieved on April 19, 2017 URL www.lxcat.net/Biagi

[19] Phelps database data retrieved on June 27, 2014 URL www.lxcat.net/Phelps

[20] Braun M, Marienfeld S, Ruf M W and Hotop H 2009 Journal of Physics B: Atomic, Molecular and Optical Physics 42125202 URL http://stacks.iop.org/0953$4075 / 42 / i=12 / a=125202$

[21] Verhaart H F A and van der Laan P C T 1984 Journal of Applied Physics 55 3286-3292 URL https://doi.org/ 10.1063/1.333364

[22] Hösl A, Häfliger P and Franck C M 2017 Journal of Physics D: Applied Physics 50485207 URL http:// stacks.iop.org $/ 0022-3727 / 50 / i=48 / a=485207$

[23] Haefliger P, Hösl A and Franck C M 2018 Journal of Physics D: Applied Physics 51355201 URL http:// stacks.iop.org $/ 0022-3727 / 51 / i=35 / a=355201$

[24] Pancheshnyi S 2013 Journal of Physics D: Applied Physics 46155201 URL http://stacks.iop.org/0022-3727/46/ $i=15 / a=155201$

[25] Wang W and Bogaerts A 2016 Plasma Sources Science and Technology $\mathbf{2 5} 055025$ URL http://stacks.iop.org/ $0963-0252 / 25 / i=5 / a=055025$

[26] UNAM database data retrieved on January 27, 2017 URL www.lxcat.net/UNAM

[27] Wooton R E 1982 Gases superior to $\mathrm{SF}_{6}$ for insulation and interruption EPRI EL-2620, Final Report

[28] Heni M, Illenberger E and Lentz D 1986 International Journal of Mass Spectrometry and Ion Processes $71199-210$ ISSN 0168-1176 URL http://www.sciencedirect.com/ science/article/pii/016811768685056X

[29] Harrison M A and Geballe R 1953 Phys. Rev. 91(1) 1-7 URL https://link.aps.org/doi/10.1103/PhysRev.91.1 